\title{
Leaf Hexane Extracts of Two Turkish Fig (Ficus carica L.) Cultivars Show Cytotoxic Effects on a Human Prostate Cancer Cell Line
}

\author{
Olcay Boyacioglu ${ }^{1}$ \\ Betül Kara' ${ }^{2}$ \\ Hilal Can ${ }^{3}$ iD \\ Tugçe Naile Yerci ${ }^{4}$ \\ Sima Yilmaz ${ }^{5}$ (D) \\ Seda Orenay Boyacioglu ${ }^{6}$
}
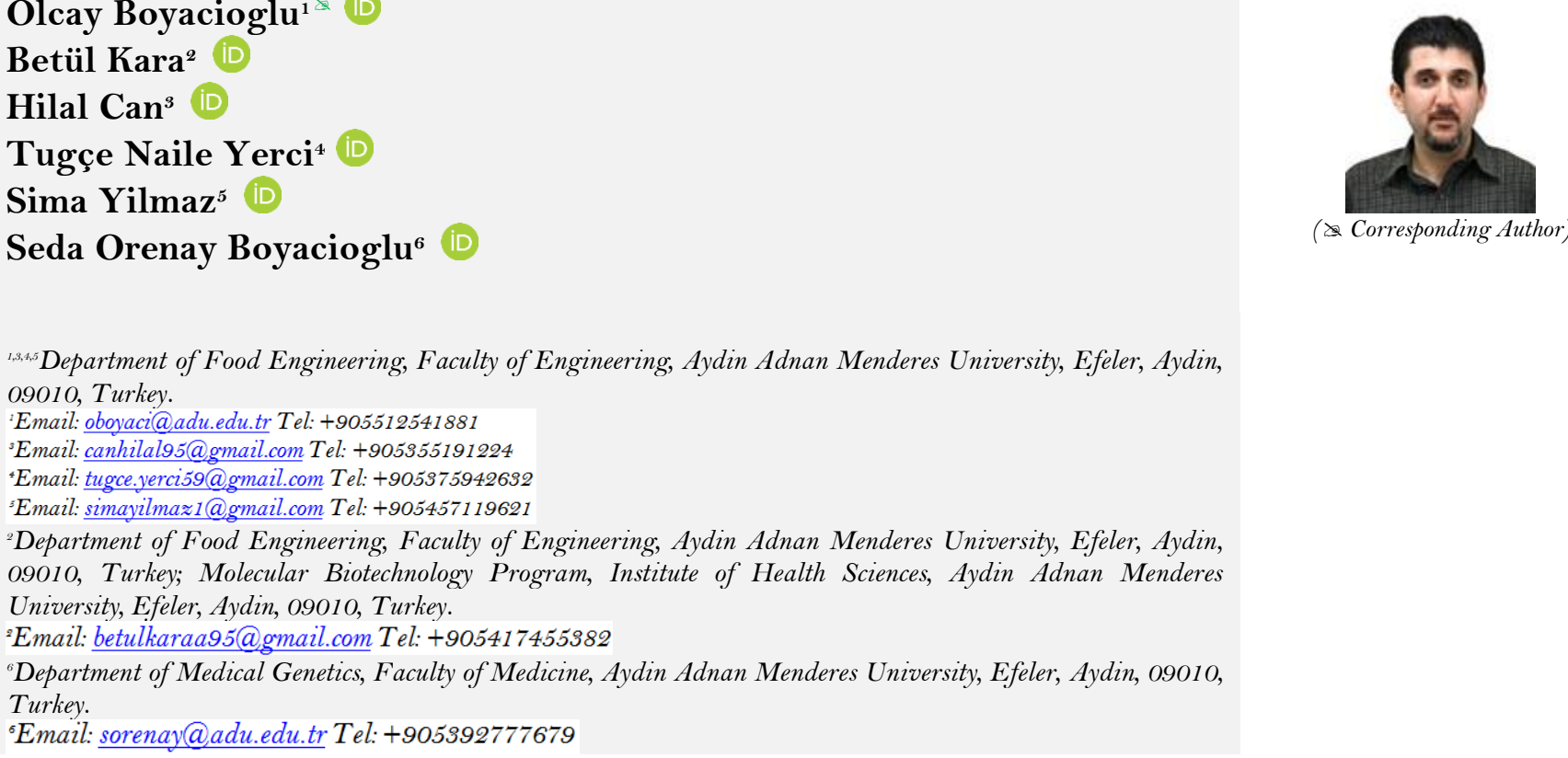

${ }^{6}$ Email:sorenay@adu.edu.trTel:+905392777679

\begin{abstract}
The world-famous Turkish fig, grown in Aydin, is also used for the treatment of various diseases with its leaves and latex. Studies have shown that fig leaf has antioxidant, antiviral, antidiabetic, antimicrobial, and anticancer effects. The objective of the study is to examine the anticarcinogenic and antimicrobial effects of nonpolar extracts from the leaves of two fig cultivars (Sari Lop and Aydin Black) that are the most widely grown in Aydin. The fig leaves collected in the summer of 2017 were dried in shade at room temperature and crumbled. The n-hexane extracts of the dried fig leaves obtained with manual soxhlet and semi-automated soxhlet apparatus were applied on PC3 human prostate cancer cell line for $24 \mathrm{~h}$. The antimicrobial activities of the extracts were examined on Escherichia coli and Bacillus cereus using disc and agar well diffusion methods. As a result, antimicrobial activity of the n-hexane extracts on the bacteria was not detected at the highest dose tested $(100 \mathrm{mg} / \mathrm{ml})$. The n-hexane extracts showed cytotoxic effect on PC3 cells in a dose-dependent fashion and caused close to $100 \%$ death at $1000 \mu \mathrm{g} / \mathrm{ml}$. No significant difference was observed between the cytotoxic effects of n-hexane extracts of two fig cultivars and the extraction methods $(\mathrm{P}>0.05)$.
\end{abstract}

Keywords: Ficus carica, Fig leaf, Hexane extract, Prostate cancer, Cytotoxicity, Antimicrobial.

Citation | Olcay Boyacioglu; Betül Kara; Hilal Can; Tugçe Naile Yerci; Sima Yilmaz; Seda Orenay Boyacioglu (2019) Leaf Hexane Extracts of Two Turkish Fig (Ficus carica L.) Cultivars Show Cytotoxic Effects on a Human Prostate Cancer Cell Line. Agriculture and Food Sciences Research, 6(1): 66-70. History:

Received: 31 January 2019

Revised: 7 March 2019

Accepted: 17 April 2019

Published: 11 June 2019

Licensed: This work is licensed under a Creative Commons Attribution 3.0 License $(\mathrm{cc})$ E

Publisher: Asian Online Journal Publishing Group
Contribution/Acknowledgement: All authors contributed to the conception and design of the study. Bacterial strains were generously gifted by Prof. Dr. H. Halil Bıyık, and the PC3 cell line by Prof. Dr. William H. Gmeiner. Funding: This work was supported by the Scientific and Technological Research Council of Turkey (TUBITAK), BIDEB 2209-A program, Grant number 1919B011700595 to BK.

Competing Interests: The authors declare that they have no conflict of interests.

Transparency: The authors confirm that the manuscript is an honest, accurate, and transparent account of the study was reported; that no vital features of the study have been omitted; and that any discrepancies from the study as planned have been explained.

Ethical: This study follows all ethical practices during writing.

\section{Contents}

1. Introduction

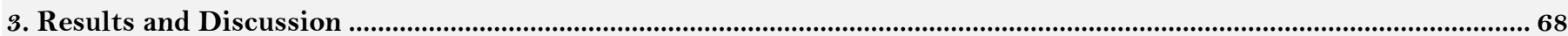

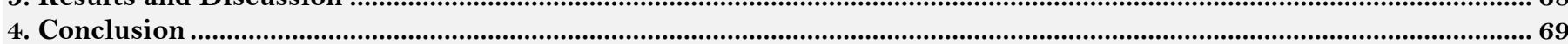

References 


\section{Introduction}

Fig (Ficus carica L.), a fruit tree of the Moraceae family, is a small tree with a height ranging from 1 to $10 \mathrm{~m} . \mathrm{F}$. carica plant is grown mostly in the city of Aydin in Aegean Region of Turkey [1]. The fig is cultivated worldwide for its nutritive and medical properties. It is widely used in Ayurveda, siddha, and homeopathy medical systems [2]. Fruits, leaves, and roots of fig plants are some of the remedies people resort to in various illnesses. While fig fruit is used for the prevention of indigestion, anorexia, cardiovascular problems, and cancers; fig roots and leaves are used against indigestion and anorexia. In addition, fig leaf is also used against the anemia [3]. The total phenolic substance, organic acid content, and antioxidant potential in the fig leaf have been reported to be higher than in fig pulp and crusts [4].

It is claimed that F. carica is useful in treating liver and spleen disorders and gout disease. Fig leaves were also tried for the treatment of jaundice. F. carica leaves boiled in hot water were reported to be used in kidneys and liver, in diabetes and calcification, and as well as in hemorrhoid treatment $[5,6]$. F. carica leaves have also been used in the treatment of vitiligo due to the presence of furanocoumarins, psoralen, and daidzein [7]. The fig leaf is also reported to be used in asthma, cough, sexual disorders, diarrhea, hematuria, earache, toothache, migraine, eye problems, stomach problems, and scabies [8]. In traditional medicine, the use of $F$. carica leaf, fruit, and root is a reality due to the antibacterial, antifungal, antioxidant, and antiviral activities it has [3].

In 1998, when the aqueous decoction of fig leaf was administered to Type I diabetic patients, hypoglycaemic effect was revealed as the postprandial (after the meal) glycemia decreased significantly in the patients [9]. Following this, Canal et al. showed that chloroform extract obtained from aqueous decoction of $F$. carica leaves was successfully used to decrease cholesterol levels and hyperglycemia on the rats with experimentally-induced diabetes [10].

It was reported that fig leaf methanol extract $(500 \mathrm{mg} / \mathrm{kg})$ decreased the aspartate aminotransferase, alanine aminotransferase, total serum bilirubin, and malondialdehyde levels, and showed liver protective effect by reducing lipid peroxidation in the liver [11]. This activity of the fig leaf extract is comparable to slymarine [12] which is known as a liver protective agent.

The petroleum ether extract of $F$. carica leaves provided promising results in the treatment of rifampicininduced hepatic damage in rats [13]. A study conducted on Wistar albino rats showed that the petroleum ether, chloroform, and ethanol extracts of $F$. carica leaves had anti-imflammatory properties [8]. In a recent study, ethyl acetate extract of fig leaf was shown to be controlling the glucose and fat levels in type 2 diabetic rats, thus being effective in controlling the carbohydrate metabolism [14]. While promising results were obtained with $F$. carica leaf extracts, ethanol extract of $F$. carica fruit (fig) up to $1000 \mathrm{ug} / \mathrm{ml}$ for $72 \mathrm{~h}$ did not show any toxicity on U87 glioblastoma cells [15].

In a study conducted in Iran, the anti-angiogenic effects of fig leaf ethanolic extract was evaluated on human umbilical vein endothelial cells (HUVEC). After 24 hours of incubation with the extract at $25 \mu \mathrm{g} / \mathrm{ml}$, a statistically significant cytotoxic effect on HUVECs was reported compared to the control group [16].

The antimicrobial effects of $F$. carica leaf extracts have been examined in several studies. The methanol extract of fig leaves collected and dried in South Korea was detected to have antimicrobial activity on oral bacteria [17]. In 2016, total phenolic and flavonoid contents of the methanol extracts from ten different varieties of $F$. carica in Algeria were examined and antimicrobial effects of the extracts were determined by disk diffusion test. As a result, all extracts were rich in phenolic compounds and had antimicrobial effect against Gram-positive and Gramnegative bacteria. Staphylococcus aureus and Bacillus cereus were reported to be the most susceptible bacteria to $F$. carica extracts [18]. In another study, the ethanol extract of fig leaf showed growth inhibitory effect against the bacteria Staphylococcus aureus, Salmonella typhi, and the mold Fusarium oxysporum. Also, fig latex was tried in this study and reported to have a stronger effect. Aspergillus niger and E. coli were more resistant to ethanolic extract and fig latex [19].

To the best of our knowledge, no results were reported on the essential oil and n-hexane extracts of fig leaves. The objectives of this study, were to assess the antibacterial and antiproliferative effects of nonpolar extracts from leaf of two Turkish fig cultivars on two bacterial samples and on PC3 human prostate cancer cell line, respectively.

\section{Materials and Methods \\ 2.1. Preparation of Fig Leaves}

The research material fig leaves were collected from the F. carica cultivar Sari Lop trees grown in the Aydin Adnan Menderes University Central Campus (37 $\left.51^{\prime} 28.3^{\prime N} 27^{\circ} 51^{\prime} 23.8^{\prime \prime E}\right)$ and F. carica cv. Aydin Black (also known as Bursa Black) leaves were collected from a fig orchard in Gencelli village of Kuyucak district in the city of Aydin $\left(37^{\circ} 56^{\prime} 04.5^{\prime \prime} \mathrm{N} 28^{\circ} 39^{\prime} 28.9^{\prime \prime} \mathrm{E}\right)$ in the summer of 2017 . The collected leaves were visually inspected not to have damage due to sunburn, plant pests, or human handling. The leaves were shade-dried at room temperature for a week and crushed. The resulting leaf pieces were stored in dry and cool room conditions.

\subsection{Determination of Water Content of the Fig Leaves}

Fresh, mature or young (leaf length $<10 \mathrm{~cm}$ ) fig leaf pieces ranging between 4 and 10 gr was weighed into a pre-weighted crucible. After 3 hours at $105^{\circ} \mathrm{C}$ in lab oven, the crucible with the sample was cooled in a desiccator and weighed again to determine the water contents.

\subsection{Essential oil extraction}

Essential oil was extracted from $100 \mathrm{gr}$ of crushed dry fig leaves mixed with $800 \mathrm{ml}$ of distilled water by 6 -hr hydrodistillation using the Clevenger-type apparatus.

\subsection{Hexane Extraction Methods}

In the first manual method, classical, glass soxhlet extraction system was used. Dried and crushed ( $24 \mathrm{gr})$ fig leaf samples in the cellulose thimbles were extracted with $300 \mathrm{ml}$ of $\mathrm{n}$-hexane for 2.5 hours. The resulting extract 
was filtered twice through Whatman No. 1 filter paper and concentrated by rotary evaporator (Büchi Labortechnik $\mathrm{AG}, \mathrm{R}-100$, Flawil, Switzerland) at $55^{\circ} \mathrm{C}$ at about 70 bar vacuum pressure. The resulting solid extract mass was weighed, diluted in n-hexane to a concentration of $0.1 \mathrm{gr} / \mathrm{ml}(10 \%)$, and stored at $-18^{\circ} \mathrm{C}$.

For the second extraction method, dried and crushed Sari Lop and Aydin Black fig leaves (a total of 24 gr in 3 cellulose thimbles) were extracted with a total of $150 \mathrm{ml}$ of n-hexane in a semi-automated soxhlet device (Velf Scienfitica, ser 148/3, 20865 Usmate, Italy). The extraction program is composed of $40 \mathrm{~min}$ immersion, $80 \mathrm{~min}$ washing, and $3 \mathrm{~min}$ recovery. At the end of the extraction, the leftover n-hexane was removed and the resulting solid extract mass was stored as described above.

\subsection{Bacterial Species}

Antimicrobial assays were performed on E. coli ATCC 35218 and B. cereus ATCC 11778 (gifted by Prof. Dr. H. Halil Bıyık, Aydın Adnan Menderes University). Bacteria were cultured in tryptic soy broth (TSB) (Merck) and tryptic soy agar (TSA) media consisting of TSB supplemented with 15\% agar agar (Sigma Aldrich).

\subsection{Disc Diffusion and Agar Well Diffusion Methods}

Fifty $\mu \mathrm{l}$ of E. coli or B. cereus culture grown in TSB for 6-8 hours was transferred onto Mueller Hinton Agar (MHA) plates (Merck) and spread over the entire surface to form a thin film layer. Ten $\mu$ of the n-hexane extract of fig leaf dissolved in n-hexane or acetone at $0.1 \mathrm{gr} / \mathrm{ml}$ concentration was impregnated into sterile $6 \mathrm{~mm}$ antimicrobial susceptibility disks (Oxoid) on the surface of MHA plate, and the discs were pressed down gently to ensure complete contact with the agar surface. The n-hexane or acetone $(10 \mu \mathrm{l})$ and a Gentamicin (Oxoid) disk were used as negative and positive controls, respectively. Plates were incubated at $37^{\circ} \mathrm{C}$ for up to $48 \mathrm{~h}$ and the bacterial growth inhibition zones around the discs were observed and measured.

Agar well diffusion assay was used to increase the amount of extract tested. After the test bacteria were spread on the MHA plates as described in the disc diffusion method, wells with $5 \mathrm{~mm}$ in diameter were formed on the agar under aseptic conditions. Each well was filled with the n-hexane extract of fig leaf dissolved in n-hexane or acetone at $0.1 \mathrm{gr} / \mathrm{ml}$ concentration. Plates were incubated and the bacterial growth inhibition zones around the discs were observed as described above.

\subsection{Prostate Cancer Cell Line Culture}

The anti-carcinogenic properties of the n-hexane extracts of the fig leaves were tested on PC3 human prostate cancer cell line (gifted by Prof. Dr. William H. Gmeiner, Wake Forest University). Cells were cultured in RPMI1640 (Sigma-Aldrich) supplemented with $10 \%$ fetal bovine serum (FBS) (Biowest) in the presence of $5 \% \mathrm{CO}_{2}$ at $37^{\circ} \mathrm{C}$. Cells were routinely passaged using Trypsin (Sigma-Aldrich) when they reached $80-90 \%$ confluence.

\subsection{Cytotoxicity MTT Assay}

PC3 cells were seeded at a density of 3000 cells/well in 96-well plate and incubated in $\mathrm{CO}_{2}$ incubator. The following day, hexane extracts were applied to the cells at $250,500,750$, and $1000 \mu \mathrm{g} / \mathrm{ml}$ concentrations for $24-48$ hours, and cell viabilities were measured colorimetrically by 3-(4,5-Dimethylthiazol-2-yl)-2,5-Diphenyltetrazolium Bromide (MTT) (Sigma-Aldrich). MTT was dissolved in sterile phosphate buffered saline (PBS) and further diluted in RPMI with $10 \%$ FBS to a final MTT concentration of $0.5 \mathrm{mg} / \mathrm{ml}$. At the end of the fig leaf extract treatment, the used media was replaced with $120 \mu \mathrm{l}$ of new media with MTT. After a minimum 3 hours of incubation, the violet colored formazan crystals inside the cells were observed under a microscope, and the MTT containing media was replaced with $100 \mu \mathrm{l}$ of dimethyl sulfoxide (DMSO) (Merck). After the plate was shaken for 10 min to dissolve the formazan crystals, results were obtained with a spectrophotometer (Thermo Labsystems Multiskan Spectrum Mic) at $570 \mathrm{~nm}$. All experiments were performed in triplicates and the experiments were repeated 3 times.

\section{Results and Discussion}

The water contents of fresh, mature fig leaves and the young leaves (leaf length $<10 \mathrm{~cm}$ ) for both fig cultivars were found to be 70 and $78 \%$, respectively. These values are correlated with the water content of mint leaves, which was reported as $70-80 \%$ [20].

Essential oil extraction from both fig cultivar leaves was not possible as no essential oil was observed after the water distillation method using Clevenger apparatus, possibly due to low amount of essential oil in the leaves. To check the equipment functionality, essential oil of Thymus vulgaris L. was successfully extracted. A larger volumed extraction system might help in extracting essential oil from fig leaves.

The n-hexane extraction yield rates of $F$. carica leaves in manual and semi-automated soxhlet methods were 1.55 and $2.30 \mathrm{mg} / \mathrm{gr}$, respectively for the Sari Lop cultivar and 2.15 and $2.40 \mathrm{mg} / \mathrm{gr}$, respectively for the Aydin Black cultivar.

First, the $F$. carica leaf extracts prepared at $10 \%$ concentration in n-hexane were used in disc diffusion tests Table 1. However, considering the low volume of extract used in discs and the fast vaporizing nature of $n$-hexane, no antibacterial effect of the extracts or the n-hexane negative control was observed. For this reason, the n-hexane extracts were solubilized in acetone at $10 \%$ concentration but no antimicrobial effect on the growth of $E$. coli and $B$. cereus was observed either Table 1. The negative control acetone showed greater antimicrobial effect than all of the extracts. None of the fig leaf extracts obtained by Semi-automated soxhlet system and dissolved in acetone had antimicrobial effect against B. cereus. Similar results were obtained in well diffusion tests (results not shown). 
Table-1. Result of disc diffusion tests using the n-hexane extract of fig leaves dissolved in n-hexane or acetone.

\begin{tabular}{|c|c|c|c|}
\hline \multirow{2}{*}{$\begin{array}{c}\text { Extraction } \\
\text { solvent }\end{array}$} & \multirow[t]{2}{*}{ Reagents tested } & \multicolumn{2}{|c|}{ Diameter of growth inhibition zone (mm) } \\
\hline & & E. coli ATCC 35218 & B. cereus ATCC 11778 \\
\hline None & $\begin{array}{c}\text { Gentamicin } \\
\text { (Pos. control) }\end{array}$ & 12 & 21 \\
\hline \multirow{5}{*}{ n-hexane } & $\begin{array}{c}\text { n-hexane } \\
\text { (Neg. Control) }\end{array}$ & 6 & 6 \\
\hline & Sari Lop M & 6 & 6 \\
\hline & Sari Lop S & 6 & 6 \\
\hline & Aydin Black M & 6 & 6 \\
\hline & Aydin Black S & 6 & 6 \\
\hline \multirow{5}{*}{ acetone } & $\begin{array}{c}\text { Acetone } \\
(\text { Neg. Control) }\end{array}$ & 15 & 15 \\
\hline & Sari Lop M & 12 & 12 \\
\hline & Sari Lop S & 8 & 6 \\
\hline & Aydin Black M & 10 & 10 \\
\hline & Aydin Black S & 13 & 6 \\
\hline
\end{tabular}

However, a recent study conducted in Algeria reported that methanol extracts of 10 different varieties of $F$. carica leaves showed antimicrobial properties against Gram positive and Gram negative bacteria [18]. Type of extraction solvent used, geographic and climatic differences between Turkey and Algeria, and the type of the fig trees may be counted as the potential reasons for the difference in antimicrobial effectiveness between the studies. Another study conducted in South Korea with fig leaf methanol extract also reported antimicrobial effect against the oral bacteria [17]. In 1998, hypoglycemic effect of fig leaf was investigated in type I diabetic patients [9] and in 2000, a chloroform extract from $F$. carica leaves was used to reduce cholesterol levels in diabetic mice [21].

In this study, cytotoxic effects of n-hexane extract of fig leaves collected from two local cultivars (Sari Lop and Aydin Black) grown in Aydin, Turkey were investigated on the PC3 human prostate cancer cell line. Fig leaf extracts were applied on cells at doses ranging from $0-1000 \mu \mathrm{g} / \mathrm{ml}$ for $24 \mathrm{~h}$. Results reveal that fig leaf extracts showed cytotoxic effect on PC3 cells in a dose-dependent manner Figure 1. The leaf extracts started showing 50\% cytotoxicity on PC3 cells after $24 \mathrm{~h}$ treatment at $250 \mu \mathrm{g} / \mathrm{ml}$ dose. Almost complete cytotoxicity was observed on PC3 cells after $24 \mathrm{~h}$ treatment at $1000 \mu \mathrm{g} / \mathrm{ml}$. No statistically significant difference was available between the cytotoxic effects of Sari Lop and Aydin Black cultivars (t-test, $\mathrm{P}>0.05$ ). Also, there was no significant difference in the comparison of the extraction type (manual soxhlet vs. semi-automated soxhlet device) (t-test, $\mathrm{P}>0.05)$.

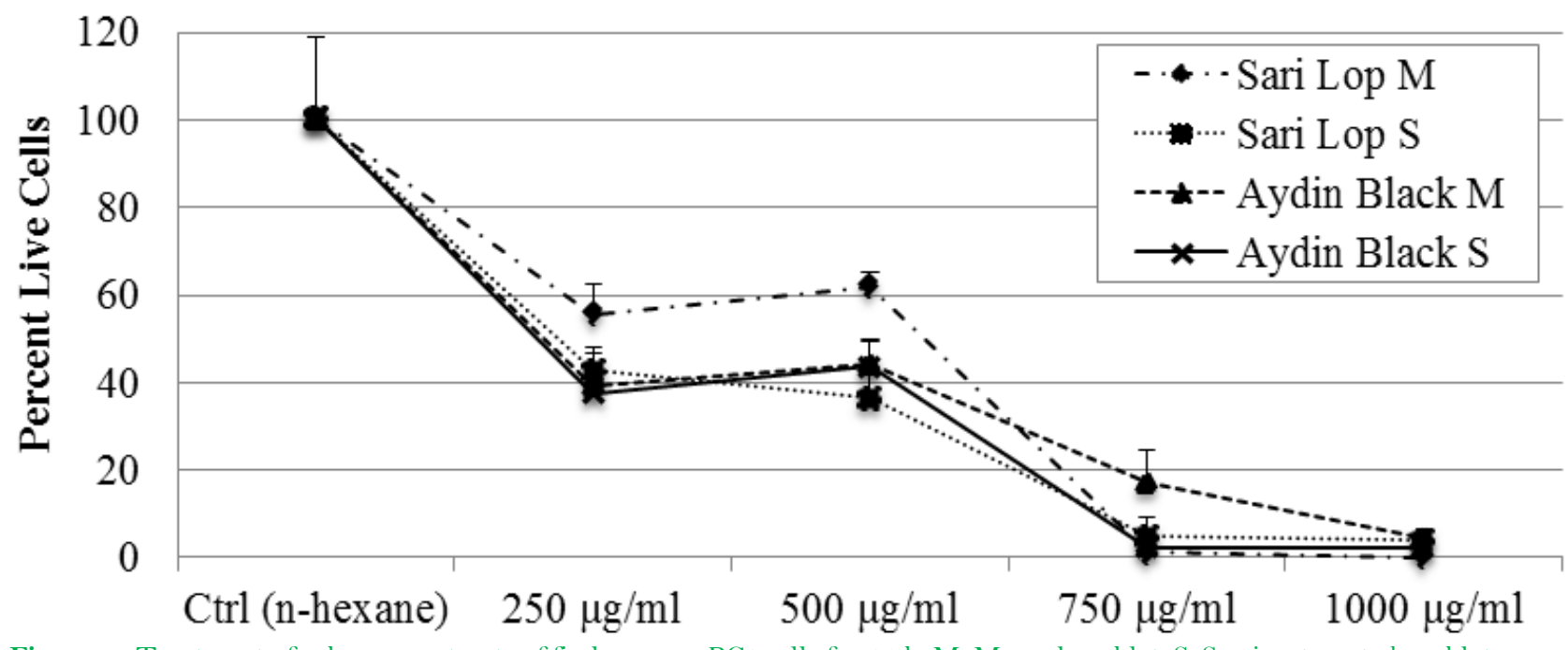

Figure-1. Treatment of n-hexane extracts of fig leaves on PC3 cells for 24 h. M: Manual soxhlet; S: Semi-automated soxhlet.

The petroleum ether extract of $F$. carica leaf was successfully used in rats to protect the liver from damage by rifampicin [13]. Similarly, hepatoprotective effects of fig leaf ethanol [22] and methanol [23] extracts were reported against hepatotoxicity caused by carbon tetrachloride. Ethanol extract of fig leaf was reported to have a curing effect against both cellular and humoral antibody response in mice [24]. It was also indicated that fig leaf ethanol extract has immunity stimulating effect. Additionally, the water extract of fig leaf is known to have toxicity against herpes simplex virus [25].

\section{Conclusion}

In conclusion, $F$. carica fruit, latex, and leaf have been researched for their beneficial effects by various studies. This study revealed that $24 \mathrm{~h}$ treatment of n-hexane extract of two fig cultivars shows cytotoxic effect on PC3 human prostate cancer cell line.

\section{References}

[1] N. Günal, "The culture of figs in Turkic world," Turkish Stud, vol. 3, pp. 561-581, 2008. Available at: https://doi.org/10.7827/turkishstudies.440.

[2] S. Stephen Irudayaraj, S. Christudas, S. Antony, V. Duraipandiyan, A.-D. Naif Abdullah, and S. Ignacimuthu, "Protective effects of Ficus carica leaves on glucose and lipids levels, carbohydrate metabolism enzymes and $\beta$-cells in type 2 diabetic rats," Pharmaceutical Biology, vol. 55, pp. 1074-1081, 2017. Available at: https://doi.org/10.1080/13880209.2017.1279671.

[3] S. Mawa, K. Husain, and I. Jantan, "Ficus carica L.(Moraceae): Phytochemistry, traditional uses and biological activities," EvidenceBased Complementary and Alternative Medicine, vol. 2013, pp. 1-8, 2013. Available at: https://doi.org/10.1155/2013/974256. 
[4] A. Solomon, S. Golubowicz, Z. Yablowicz, S. Grossman, M. Bergman, H. E. Gottlieb, A. Altman, Z. Kerem, and M. A. Flaishman, "Antioxidant activities and anthocyanin content of fresh fruits of common fig (Ficus carica L)," Journal of Agricultural and Food Chemistry, vol. 54, pp. 7717-7723, 2006. Available at: https://doi.org/10.1021/jfo60497h.

[5] T. K. Lim, Ficus carica In: Edible medicinal and non medicinal plants. Fruits, vol. 3. Dordrecht: Springer, 2012.

[6] C. Pérez, E. Domínguez, J. M. Ramiro, A. Romero, J. E. Campillo, and M. D. Torres, "A study on the glycaemic balance in streptozotocin-diabetic rats treated with an aqueous extract of Ficus carica (Fig tree) leaves," Phyther Res, vol. 10, pp. 82-83, 1996.

[7] B. Ali, M. Mujeeb, V. Aeri, S. R. Mir, M. Faiyazuddin, and F. Shakeel, "Anti-inflammatory and antioxidant activity of Ficus carica Linn. leaves," Natural Product Research, vol. 26, pp. 460-465, 2012.

[8] V. V. Patil and V. R. Patil, "Evaluation of anti-inflammatory activity of Ficus carica Linn. leaves," Indian Journal of Natural Products and Resources, vol. 2, pp. 151-155, 2011.

[9] A. Serraclara, F. Hawkins, C. Pérez, E. Domínguez, J. E. Campillo, and M. D. Torres, "Hypoglycemic action of an oral fig-leaf decoction in type-I diabetic patients," Diabetes Research and Clinical Practice, vol. 39, pp. 19-22, 1998. Available at: https://doi.org/10.1016/s0168-8227(97)00112-5.

[10] J. R. Canal, M. D. Torres, A. Romero, and C. Pérez, "A chloroform extract obtained from a decoction of Ficus carica leaves improves the cholesterolaemic status of rats with streptozotocin-induced diabetes," Acta Physiologica Hungarica, vol. 87, pp. 71-76, 2000. Available at: https://doi.org/10.1556/aphysiol.87.2000.1.8.

[11] M. Mujeeb, S. Alam Khan, V. Aeri, and B. Ali, "Hepatoprotective activity of the ethanolic extract of Ficus carica Linn. leaves in carbon tetrachloride-Induced hepatotoxicityin rats," Iranian Journal of Pharmaceutical Research, vol. 10, pp. 301-306, 2011.

[12] J. Feher and G. Lengyel, "Silymarin in the prevention and treatment of liver diseases and primary liver cancer," Current Pharmaceutical Biotechnology, vol. 13, pp. 210-217, 2012. Available at: https://doi.org/10.2174/138920112798868818.

[13] N. Y. Gond and S. S. Khadabadi, "Hepatoprotective activity of Ficus carica leaf extract on rifampicin-induced hepatic damage in rats," Indian Journal of Physiology and Pharmacology, vol. 70, pp. 364-366, 2008. Available at: https://doi.org/10.4103/0250474x.43003.

[14] S. S. Irudayaraj, S. Christudasa, S. Antony, V. Duraipandiyan, A. D. N. Abdullah, and S. Ignacimuthu, "Protective effects of Ficus carica leaves on glucose and lipids levels, carbohydrate metabolism enzymes and $\beta$-cells in type 2 diabetic rats," Pharmaceutical Biology, vol. 55, pp. 1074-1081, 2007. Available at: https://doi.org/10.1080/13880209.2017.1279671.

[15] N. Amessis-Ouchemoukh, S. Ouchemoukh, N. Meziant, Y. Idiri, D. Hernanz, and C. M. Stinco, "Bioactive metabolites involved in the antioxidant, anticancer and anticalpain activities of Ficus carica L., Ceratonia siliqua L. and Quercus ilex L. extracts," Industrial Crops and Products, vol. 95, pp. 6-17, 2017 . Available at: https://doi.org/10.1016/j.indcrop.2016.10.007.

[16] Z. Ghambarali, A. Bidmeshkipouri, H. Akrami, M. Azadbakht, and A. Rabzia, "Ethanolic extract of Ficus carica leave suppresses angiogenesis by regulating VEGF-A and integrin $\beta 3$ mRNA Expression in Human umbilical vein endothelial cells," Indian Journal of Physiology and Pharmacology, vol. 58, pp. 407-415, 2014.

[17] M.-R. Jeong, H.-Y. Kim, and J.-D. Cha, "Antimicrobial activity of methanol extract from Ficus carica leaves against Oral Bacteria," Journal of Bacteriology and Virology, vol. 39, pp. 97-102, 2009. Available at: https://doi.org/10.4167/jbv.2009.39.2.97.

[18] S. Mahmoudi, M. Khali, A. Benkhaled, K. Benamirouche, and I. Baiti, "Phenolic and flavonoid contents, antioxidant and antimicrobial activities of leaf extracts from ten Algerian Ficus carica L. varieties," Asian Pacific Journal of Tropical Biomedicine, vol. 6, pp. 239-245, 2016. Available at: https://doi.org/10.1016/j.apjtb.2015.12.010.

[19] K. I. Rashid, N. M. Mahdi, M. A. Alwan, and L. B. Khalid, "Antimicrobial activity of fig (Ficus carica Linn.) leaf extract as compared with latex extract against selected bacteria and fungi," Journal of University Applied Sciences, vol. 22, pp. 1620-1626, 2014.

[20] T. Koyun and H. B. Yilmaz, "Experimental investigation of mint drying by cabin type dryer blowing in upper and bottom," Heat Science and Single Derg, vol. 36, pp. 147-154, 2016.

[21] J. R. Canal, M. D. Torres, A. Romero, and C. Pérez, "A chloroform extract obtained from a decoction of Ficus carica leaves improves the cholesterolaemic status of rats with streptootocin-includede diabetes," Acta Physiologica Hungarica, vol. 87, pp. 71-76, 2000. Available at: https://doi.org/10.1556/aphysiol.87.2000.1.8.

[22] N. Aghel, H. Kalantari, and S. Rezazadeh, "Hepatoprotective effect of Ficus carica leaf extract on mice intoxicated with carbon tetrachloride," Iranian Journal of Pharmaceutical Research, vol. 10, pp. 63-68, 2011.

[23] G. Krishna Mohan, E. Pallavi, B. Ravi Kumar, M. Ramesh, and S. Venkatesh, "Hepatoprotective activity of Ficus carica Linn. leaf extract against carbon tetrachloride-induced hepatotoxicity in rats," DARU J Pharm Science, vol. 15, pp. 162-166, 2007.

[24] V. V. Patil, S. C. Bhangale, and V. R. Patil, "Studies on immunomodulatory activity of Ficus carica," International Journal of Pharmacy and Pharmaceutical Sciences, vol. 2, pp. 97-99, 2010.

[25] G. Wang, H. Wang, Y. Song, C. Jia, Z. Wang, and H. Xu, "Studies on anti-HSV effect of Ficus carica leaves," Zhong Yao Cai, vol. 27, pp. 754-756, 2004. 